simultaneous transplantation of both anterior and posterior lobes, showed remarkable effect on the polyurea and thirst.

Later their condition took a turn for the better as a result of repeating transplantation of calf pituitary.

The third case was 26 years old horse-man and he was beginning to suffer from polyurea and thirst about three weeks after a fall from the horse.

In this case the patient was observed his prognosis without specific treatment, but after six months process, he recovered spontaneously from polyurea and other subjective symptoms.

From these results, we would be proper to consider that this disease take a good prognosis without specific therapy, while the transplantation of calf hypophysis prove the remarkable effect.

\title{
Studies on the determination of urinary Aldosterone and other individual Corticosteroids.
}

Toshihiro SUZUKI

Oshima Clinic of Internal Medicine. Nihon University Medical School.

Metabolism of body fluids and electrolytes which related not only to aldosterone alone but to other corticosteroids, for example, glucocorticoids had mineral action. And the simultaneous administration of aldosterone and corticosterone consistently resulted in a greater potassium diuresis than did the aldosterone alone.

Therefore, body fluids and electrolytes are aummation of many corticosteroids which had biological action, and can't know by the determination of simple corticosteroids.

The author report on the systemic determination of aldosterone, Comp. B, Comp. E, Comp. F, and the newly separated contaminants.

Method :

The 24 hours urine specimen is pooled at $5^{\circ} \mathrm{G}$ and acidified to $\mathrm{pH} 1.5$ with conc. HCL, then standing 24 hours at $15^{\circ} \mathrm{C}$.

Urine was extracted by chloroform and dried. Extract was treated with Florisil column chromatographies and 4 consecutered and different paper chromatographies with Chloroform-Formamide System, Bush-C System, $\mathrm{E}_{2} \mathrm{~B}$ System, and Bush-B $\mathrm{B}_{5}$ System, to separated corticosteroid partitions.

Results :

1. Recoveries of $5 \mathrm{mg} / 100 \mathrm{ml} \mathrm{H}_{2} \mathrm{O}$ standard samples after 5 times continued extraction by 0.1 volume chloroform, for Comp. B, Comp. E, and DOC is $95 \%$, and Comp. F is $83 \%$.

2. Additional chloroform re-extraction, Comp. B, Comp. E, and DOG do not appear in the 7th chloroform extraction, but Comp. F appear in the amount of $60 \mu \mathrm{g}$ in 8 th chloroform and 9th extraction is nothing, thus this determination necessitate at least 8 consecutered extractions.

3. Comp. B,Comp. E, and Comp. F appear in $25 \%$ methanol in chloroform fraction by the use of the Florisil column chromatography is made, and recovery is about $100 \%$ in condition of 60 drops/ minutes.

4. Separate Comp. III, Comp. V, Comp. VI, and Comp. VII from aldosterone partition in NeherWettstein's method. 
5. New contaminants were discover from Comp. E and Comp. F partition after Bush-G System paper chromatography, called Comp. $\mathrm{E}_{2} \sim \mathrm{E}_{4}$, Comp. $\mathrm{F}_{2} ;$ and, other conatminants named $\mathbf{M}_{1} \sim \mathrm{M}_{3}$ $\mathrm{Z}_{1} \sim \mathrm{Z}_{8}, \mathrm{HC}_{1} \sim \mathrm{HC}_{3}, \mathrm{AC}_{1}$ and $\mathrm{AC}_{2}$ in Chloroform-Formamide and Bush-C System paper chromatography.

6. Examination of the purities of Comp. B, Comp. E, Comp. F, and aldosterone partitions is made use of the ultra violet absorption spectrum, and necessitates 4 ( $\mathrm{C}-\mathrm{F} \rightarrow \mathrm{Bush}-\mathrm{C} \rightarrow \mathrm{E}_{2} \mathrm{~B} \rightarrow \mathrm{Bush}-\mathrm{B}_{5}$ ), or $3\left(\mathrm{C}-\mathrm{F} \rightarrow \mathrm{E}_{2} \mathrm{~B} \rightarrow\right.$ Bush- $\mathrm{B}_{5}$ ), paper chromatographies to satisfactorily separate these compounds.

7. The $\mathrm{H}_{2} \mathrm{SO}_{4}$ chromogen spectrum of these partition correspond with the standard compounds. 


\title{
Aldosterone を中心とした尿中 Corticosteroids
}

\author{
分離定量法に関する研究
}

\author{
日本大学医学部大島内科学教室（指導 大島研三教授） \\ 鈴木 敏弘
}

緒言

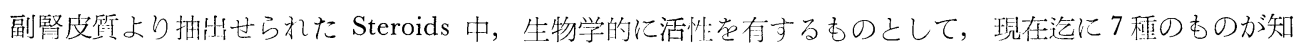
られている。

これらは，关の生物学的作用から考えて 2 種類に大別されている。

すなわち，主として糖啠代謝関与するとてろの Glucocorticoids，および主として鉱岓代謝に関与する Mineralocorticoids である.

Mineralocorticoids としては, 從来は $\Delta^{4}$-Pregnene-21-ol-3,20-dione (11-Desoxycorticosterone, DOC) が その主体をなすすのとされていたが，Simpson および Tait ${ }^{\left.\left.\left.1{ }^{122}\right) ， さ ら に ~ N e h e r ， W e t t s t e i n ， R e i c h s t e i n "\right) 4\right) ~ ら に ~}$ より DOCより一層強力な鉱所作用をもつCorticoid が発見され，乙れが $\Delta^{4}$-Androstene-3,11,17-trioneな る物斦であることがわかり，Aldosterone という名称で乎ばれ，Na 貯溜効果は DOC の25倍，K排泄効果 は 5 倍といわれ，以来，水および電解啠代謝の面において，乙の物领が注目をあつぬて来た。

林邦においては，1957年小田，石井らにより尿中 Aldosterone の定量法が発表された占ののを最初として， 以後, 木態性高血圧症の内分泌性因子，および体液電解質代謝の因子としての Aldosterone について, 各 う面での研究が盛んとなり, 著者らの教室であ, 幾多の論文として発表して来だ〉8).

小田一石井法による Aldosterone 定量泊は Peter Bent Briham Hospital での方法を基礎として，てれ に Neher-Wettstein 法の長所をとりいれ，改良した方法である.

この方法は Chloroform にて抽出した粗抽出物を Florisil column chromatography9) の後に，2つの paper chromatography を組合せ，第 1 に Hydrocortisone を分離し，第 2 そ Cortisone を分離し，乙れ により分けられた Aldosterone 相当の Band を定量に供していた.

しかるに Nowacynski ${ }^{10)}$ らによつて，乙のう江で最終的に得られたものの中にお，なおいろいろの conta-

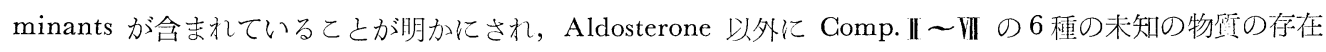
が報告された。

他方, Aldosterone, DOC 以外飞生物学的活性を有する Corticoids として, 次の 5 種のものが知られて いる.

1) $\Delta^{4}$-Pregnene-17 $\alpha, 21$-diol-3,11,20-trione (Cortisone)

2) $\Delta^{4}$-Pregnene-11 $\beta, 17 \alpha, 21$-triol-3,20-dione (Hydrocortisone)

3) $\Delta^{4}$-Pregnene-11 $\beta, 21$-diol-3,20-dione (Corticosterone)

4) $\Delta^{4}$-Pregnene-17 $\alpha, 21$-diol-3,20-dione (17 $\alpha$-hydroxy-DOC)

5) $\Delta^{4}$-Pregnene-21-ol-3,11,20-trione (11-Dehydrocorticosterone)

これらの Corticoids は一概に Mineralocorticoids, Glucocorticoids と分けられているが, Glucocortcioids にも鉱犋作用があり，また Mineralocorticoids にあ糖啠に対する作用のあることが知られている ${ }^{11) . ~}$

したがつて，鉱質代謝作用を代表するむのが Aldosterone であるとはいえ，単仁 Aldosterone のみを测 定して，生体内における複雑な水および電解啠代謝を言及することは危険である.

生体内における体液諸相の变化汇関与するのは，乙れらの Corticoids の鉱啠作用の綜合されたものであ 


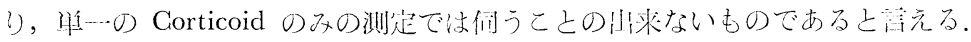

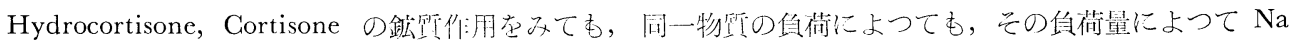

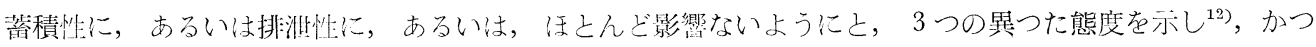

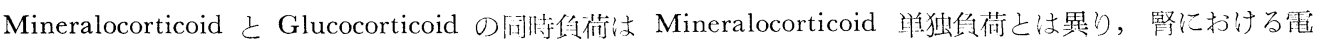
解質出納の面で大分異なる效果を現すと多知られている。

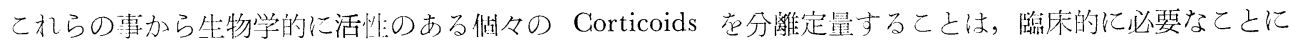
なつてくるのであるが，系統的にこれらの分離定量についての知見はなく，Aldosterone 定量にのみとどま つている.

著者は Aldosterone 定量汒について再恰詪を行うと同時に，永中における Corticoids の分滩定量法につ いて得た知見を報告する。

なお，本論交中における Corticoids の名称は Kendall に從い，Corticosterone は Comp. B, Cortisone は Comp. E, Hydrocortisone

\section{実 験 対 象}

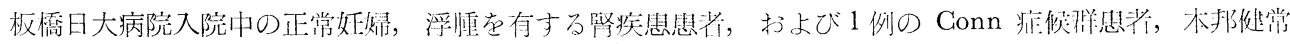
成年男子の 24 時間厡草刘像とした。

\section{実 験 方 法}

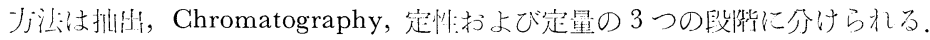

\section{A. 抽出}

$5^{\circ} \mathrm{C}$ 冷暗所に 24 時間堷尿を行い，乙杞を conc $\mathrm{HCl}$ にて $\mathrm{pH} 1.5$ とし， $15^{\circ} \mathrm{C} に て 24$ 時間加水分解を行つ たのち，0.1容の chloroform にて 5 回連続抽兆を行う。

抽出した chloroform は, その0.1容の $\underset{10}{\mathrm{~N}} \mathrm{NaOH}$ にて 2 回, 次いで同じく 0.1 容の蒸溜水にて 2 回洗鿟 し, 芒硝にて脱水後, rotary flash evaporator にて減圧乾国与る。

これを約 $10 \mathrm{ml} の$ chloroform に溶解し，次の chromatography によつて純化してゆく.

B. Chromatography.

\section{Florisil column chromatography.}

95\% ethanol にてよく洗涤した60〜100 mesh の Florisil を600ㄷに 4 時間活性:化し，乙れを混式にて

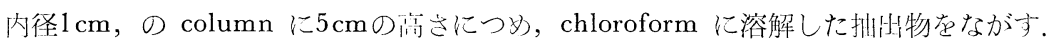

次いで chloroform $5 \mathrm{ml}, 1 \%$ methal in chloroform $25 \mathrm{ml}, 25 \%$ methanol in chloroform $50 \mathrm{ml}$ 流 し，この $25 \%$ fraction を採取し，幹闾して paper chromatography に供する。

\section{Paper chromatography.}

i) Chromatography tank.

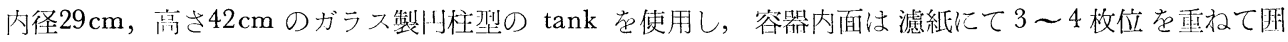
む. 固定層を必要とする $\mathrm{iii}$ ～～v）の system の埸命は，滤紙で内画を四んだ後に，别の滤紙を矩玥におつ

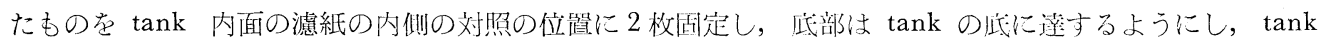
の底においた $100 \mathrm{ml}$ 容量のガラス・コップ内に入れる.

固定層はこのガラス・コップに入れ，tank の底には移動周を入れておく，

Chromatography に使用した濾紙は Whatman No.1 滤紙である.

ii) Chloroform-Formamide System (C-F System) ${ }^{1.9}$

formamide $6 \mathrm{ml}$ に aceton $14 \mathrm{ml}$ を加え混合し，乙れにWhatman No.1 滤紙を浸し，余分の液を滤紙に て平等に财いとり，直ちに陚料を少量の chloroform に溶解し， start lineにのせる. 


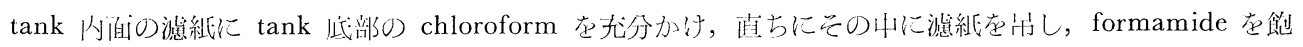

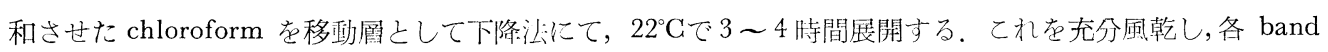
を切りとり methanol にて溶出し，乾固したものを次の system にかける。

iii) Bush-C System ${ }^{14}$

溶媒は toluen : methanol : ethyl acetate：water (225: 125:25:125) で，これを混利し，放品すると

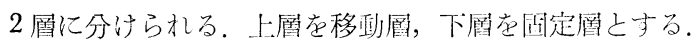

tank 内面の濾紙に移動層を，コップに下げてある矩形の濾紙に固定層をかけ，試料をつけた滤紙を吊し， $37^{\circ} \mathrm{C}$ にて 3〜4 時間展開し，滤紙在瑶乾したのち，各 band をきりとり，次の system に倛与るように methanol で溶出する.

iv) $\mathrm{E}_{2} \mathrm{~B}$ System $\left.{ }^{15}\right)$

溶媒は iso-octane : tert buthanol : water (500:250:450) で, 前者と同じく上層を移動㬝, 下層在国定 層とし Bush-C system と同じように tank を処䍜して，28にて10〜14㭙間展開する。この後に，さらに 次の system を用いる。

v) Bush-B ${ }_{\tilde{s}}$ System.

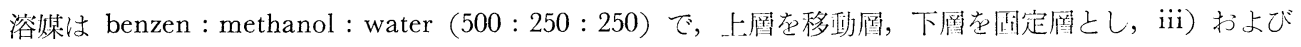

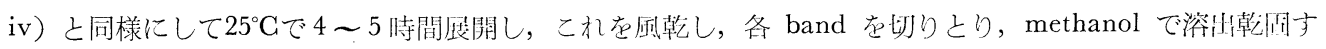
る.

\section{C. 定性および定量}

\section{1. 定性}

i) Ultra violet absorption spectrum

試料約 $40 \mu \mathrm{g}$ を95\% ethanol $3 \mathrm{ml}$ に溶解し，210～350m $\mu$ の波長で收収曲線を求妨た。

ii) $\mathrm{H}_{2} \mathrm{SO}_{4}$ chromogen spectrum ${ }^{16) \sim 18)}$

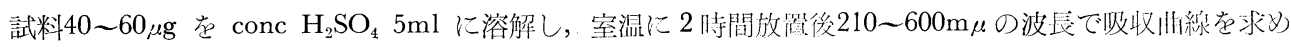
た.

\section{2. 定量}

同一試料について，次の 2 種類の片法によつて定量を行つた。

i). 紫外線吸収法 (UV 法)

standard Comp. F を使用し $239 \mathrm{~m} \mu$ における standard curve 在作成し，乙れと試料を比校し测定し た.

试料は $95 \%$ ethanol $3 \mathrm{ml}$ に溶解して行つた.

ii) Blue tetrazolium 還元江: (BT 汒i)

Nowacynski らの blue tetrazolium 反応に從い発色し $510 \mathrm{~m} \mu$ において測䇥した.

测定には Beckman 型 spectrophotometer (島洲製作所製 QB 50型)， paper にわける spot の碓認には Mineralight V-41 型(Ultraviolet products U.S.A.) 焎射のもとに photocopy t行い，目们の Band 在 切りとつた.

\section{成績}

\section{A. 抽出}

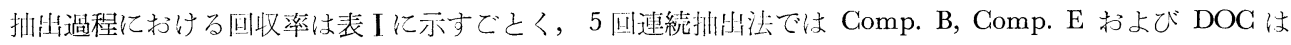
有差の差はみとめられず，93.58〜96.5\%であり，Comp. F は82.34，84.02\%であり，Comp. B, Comp. E および DOG は Comp. F よりも回収率がよい.

5 回連続抽出後の残部水層を，さらに0.1容の chloroform で抽出すると，Comp. B, Comp. E および DOG では 7 回目以後は，chloroform 中に試料を検出し得ないが，Comp. F では 8 回目に抽出した chloroform 中にも試料の残存がるられる. Aldosteroneについては，その純未を所何しないので，施䘕しなかつ 
表 I Extraction

\begin{tabular}{|c|c|c|c|c|c|}
\hline Samples & \multicolumn{2}{|c|}{$I \sim V$} & VI & III & VㄴII \\
\hline Comp. B & $4.735 \mathrm{mg}$ & $94.7 \%$ & $104 \gamma$ & 0 & 0 \\
\hline $5 \mathrm{mg}$ & 4.809 & $96.2 "$ & $87 \gamma$ & 0 & 0 \\
\hline Comp. E & 4.823 & $96.5 " \prime$ & $60 \gamma$ & 0 & 0 \\
\hline $5 \mathrm{mg}$ & 4.679 & $93.6 " \prime$ & $94 \gamma$ & 0 & 0 \\
\hline Comp. F & 4.201 & $84.0 \prime \prime$ & $634 \gamma$ & $281 \gamma$ & $84 \gamma$ \\
\hline $5 \mathrm{mg}$ & 4.117 & $82.3 \prime$ & $680 \gamma$ & $329 \gamma$ & $95 \gamma$ \\
\hline $\begin{array}{l}\text { DOC } \\
5 \mathrm{mg} \\
\end{array}$ & 4.825 & $96.5 "$ & $59 \gamma$ & 0 & 0 \\
\hline
\end{tabular}

表 II A Column Chromatography 60 drops/min.

\begin{tabular}{|c|c|c|c|c|}
\hline \multicolumn{2}{|c|}{ Samples } & \multicolumn{2}{|c|}{$\begin{array}{l:l}\mathrm{CHCl}_{3} & 1 \% \mathrm{M}-\mathrm{C} \\
\text { fraction } & \text { fraction }\end{array}$} & $\begin{array}{l}25 \% \mathrm{M}-\mathrm{C} \\
\text { fraction }\end{array}$ \\
\hline Comp. B & $50 \gamma$ & 0 & 0 & $49.3 \gamma \quad 98.6 \%$ \\
\hline "I & $200 \gamma$ & $0.5 \gamma$ & 0 & $204.1 \gamma 102.1 \%$ \\
\hline 11 & $500 \gamma$ & 0 & 0 & $498.0 \gamma \quad 99.6 \%$ \\
\hline "1 & $3 \mathrm{mg}$ & $1.3 \gamma$ & 0 & $3.007 \mathrm{mg} \quad 100.2 \%$ \\
\hline Comp. E & $50 \gamma$ & $1.0 \gamma$ & 0 & $52.9 \gamma$ \\
\hline "I & $200 \gamma$ & 0 & 0 & $200.7 \gamma \quad 100 \%$ \\
\hline 11 & $500 \gamma$ & 0 & 0 & $523.1 \gamma 104.6 \%$ \\
\hline "l & $3 \mathrm{mg}$ & $0.3 \gamma$ & 0 & $2.976 \mathrm{mg} 99.2 \%$ \\
\hline Comp. F & $50 \gamma$ & $1.2 \gamma$ & 0 & $52.2 \gamma 104.7 \%$ \\
\hline "1 & $200 \gamma$ & $0.7 \gamma$ & 0 & $198.2 \gamma \quad 99.1 \%$ \\
\hline 11 & $500 \gamma$ & $0.7 \gamma$ & 0 & $504.0 \gamma 100.1 \%$ \\
\hline 11 & $3 \mathrm{mg}$ & $0.8 \gamma$ & 0 & $3.012 \mathrm{mg} \quad 100.4 \%$ \\
\hline
\end{tabular}

表 II B Column Chromatography 80drops/min.

\begin{tabular}{|c|c|c|c|}
\hline Samples & \multicolumn{2}{|c|}{\begin{tabular}{l|l}
$\mathrm{CHCl}_{3}$ & $1 \% \mathrm{M}-\mathrm{C}$ \\
fraction & fraction
\end{tabular}} & $\begin{array}{c}25 \% \mathrm{M}-\mathrm{C} \\
\text { fraction }\end{array}$ \\
\hline Comp. B $125 \gamma$ & $6.4 \gamma$ & $13.5 \gamma$ & $112.1 \gamma 89.7 \%$ \\
\hline $500 \gamma$ & $7.6 \gamma$ & $10.9 \gamma$ & $469.0 \gamma 93.2 \%$ \\
\hline $1250 \gamma$ & $13.6 \gamma$ & $42.0 \gamma$ & $1107.3 \gamma 88.6 \%$ \\
\hline Comp. E $125 \gamma$ & $5.1 \gamma$ & $15.7 \gamma$ & $102.2 \gamma 86.6 \%$ \\
\hline $500 \gamma$ & $10.1 \gamma$ & $17.8 \gamma$ & $453.4 \gamma 90.7 \%$ \\
\hline $1250 \gamma$ & $15.3 \gamma$ & $37.9 \gamma$ & $1132.1 \gamma 90.6 \%$ \\
\hline Comp. F $125 \gamma$ & $6.6 \gamma$ & $14.3 \gamma$ & $104 \cdot 9 \gamma 83.9 \%$ \\
\hline $500 \gamma$ & $8.6 \gamma$ & $13.5 \gamma$ & $472.0 \gamma 94.8 \%$ \\
\hline $1250 \gamma$ & $10.2 \gamma$ & $33.1 \gamma$ & $1153.7 \gamma 92.3 \%$ \\
\hline
\end{tabular}

た。

B. Column chromatography

定奘的にみると表 II A 亿示すじと く, 分時 60 滴の滴下条件ではComp. $\mathrm{B}, \mathrm{E}, \mathrm{F}$ いずれし $25 \%$ methanol in chloroform fraction に出現し, その回収率は活隹100\%である。

㵜下数在分時 80 滴とすると表 II B

に示すじとく Comp. B, E, F のい ずれも chloroform および $1 \%$ methanol in chloroform fraction に㟧現し，25\% methanol in chloroform fraction における四収率は低下する。 定州:的には，分時60滴の滴下条件.では， DOG は $1 \%$ methanol in chloroform fraction に, Comp. B,E および F は25\% methanol in chloroform fraction に出現を みた。

なお，この際の reagent blank は表川 亦すごとき optical density を示し，試料を 含むものと同様にして Chloroform，1\% お よび $25 \%$ methanol in chloroform の順に column を流し，乙れをとり，乾燥させ $95 \%$ ethanol でこの蒸発川在洗い，BT 汒で測定 したあのである。

\section{Paper chromatography.}

\section{C-F System}

Column chromatography における $25 \%$

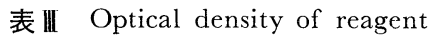
blank in Golumn Chromatography.

\begin{tabular}{c|c|c}
\hline $\begin{array}{c}\text { Chloroform } \\
\text { fraction }\end{array}$ & $\begin{array}{c}1 \% \mathrm{M}-\mathrm{C} \\
\text { fraction }\end{array}$ & $\begin{array}{c}25 \% \mathrm{M}-\mathrm{C} \\
\text { fraction }\end{array}$ \\
\hline .010 & .085 & .183 \\
.019 & .075 & .172 \\
.016 & .045 & .133 \\
.017 & .070 & .140 \\
.015 & .080 & .166 \\
.020 & .039 & .157 \\
\hline
\end{tabular}

methanol in chloroform fraction を C-F system に展開すると図 I にボすごとく，4つの Band の形成 がみられる。 
最も極性の活门ものからのバると，第 1 の band

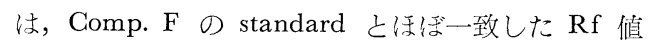
を有し Comp. F およびその他の contaminants で あろうと想像され，その Rf は 0.280 , standard Comp. E を 1 とした migration rate (MR) は 0.420であり, これを Comp. F fraction と命名し た.

第 2 のand は standard Comp. E およびFの ほば中間にみられ Rf: 0.425, MR : 0.635 走し ,M” fraction と名付けた.

第 3 のand は standard Comp.E とほぼ一致 した Rf を有するもので Rf: 0.667 で，乙の中に は Comp. E, Aldosterone およびその他の contaminants を含むむのと想像され, Comp. E fraction とした.

第 4 は最屯極性:の弱いもので Rf: $0.880, \mathrm{MR}$ : 1.29を示している band で尿色素に移行し，その境 界は明かでない，尿色素および人工の色素と思われ るものは Mineralight にて黄色の螢光としてみと められる。この band は solvent front に近く, 可成り広い巾で拡がり，精確な Rf を求めることは困難であるが standard Comp. B をとの system にな がすと，ての Band の一部になるような位置であり，ての点より，乙の band の一部には Comp. B が盒 まれるのではないかと想像される。

この band ‘ ‘” fraction と名付けた.

\section{Bush-C system}

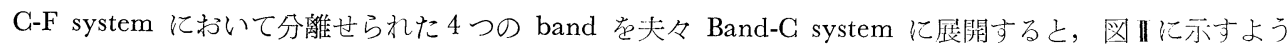
な多くの bands の形成がみられる.

i) Comp. F fraction.

C-F system の standard Comp. F 相当の band は Bush-C system そよつて standard Comp. F に一 致する band 以外に， 3 種類の未知の物質を分離した。 この bands を極性の弱いものより $\mathrm{HC}_{1} \sim \mathrm{HC}_{3}$ と命名した.すなわち $\mathrm{HC}_{1}$ は $\mathrm{Rf}: 0.42, \mathrm{MR}: 1.14$ を示すむので紫外線照射で水色の螢光带として見ら れる. $\mathrm{HC}_{2}$ は $\mathrm{Rf}: 0.185, \mathrm{MR}: 0.38, \mathrm{HC}_{3}$ は start line 直下にみられる最も極显の搔いもので $\mathrm{Rf}: 0.037$, MR : 0.10 である.

ii) " $\mathrm{M}$ " fraction

図II Bに示すごとく“M” fraction は5つの bands に分けられ，それぞれの Rf，MR は図に示す值であ る. 真中のものは standard Comp. F に一致した band として出現する。

iii) Comp. E fraction.

C-F system における Comp. E 相当の band は図 II Gに示すごとく, standard Comp. F に一致するす

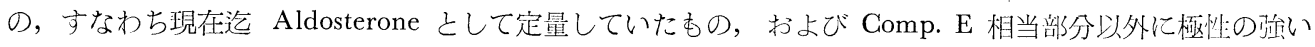

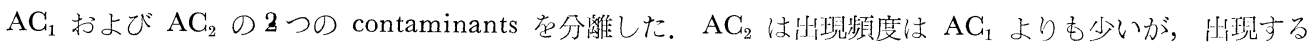
ときは量が多い.

iv) "Z" fraction

図 IIDに示すでとく“Z” fraction は Bush-G system で7つの分劃に分けられ，それぞれのRfおよび 算36卷 符 6 号 

A. Bush-G System $\mathrm{C}-\mathrm{F} \rightarrow$
"Comp. F" fraction in C-F.

RP: 0.07

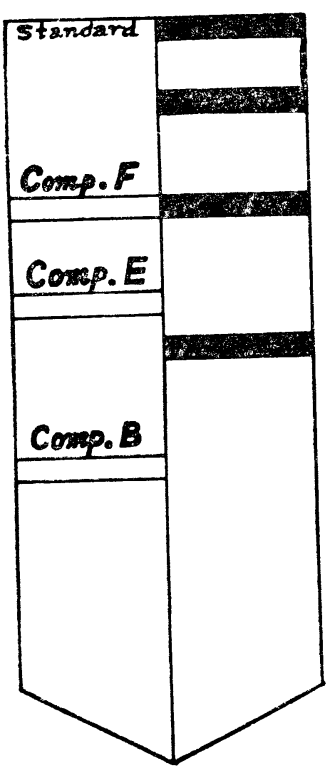

$H C_{3} \quad R R ; 0.10$

HC, $P$ : 0.185

$\mathrm{HC}_{2}$ MR: $: 38$

Hydrocortisone

HC,

図 2

C. Bush-C System

$\mathrm{C}-\mathrm{F} . \rightarrow$

"Comp. E" fraction in C-F.

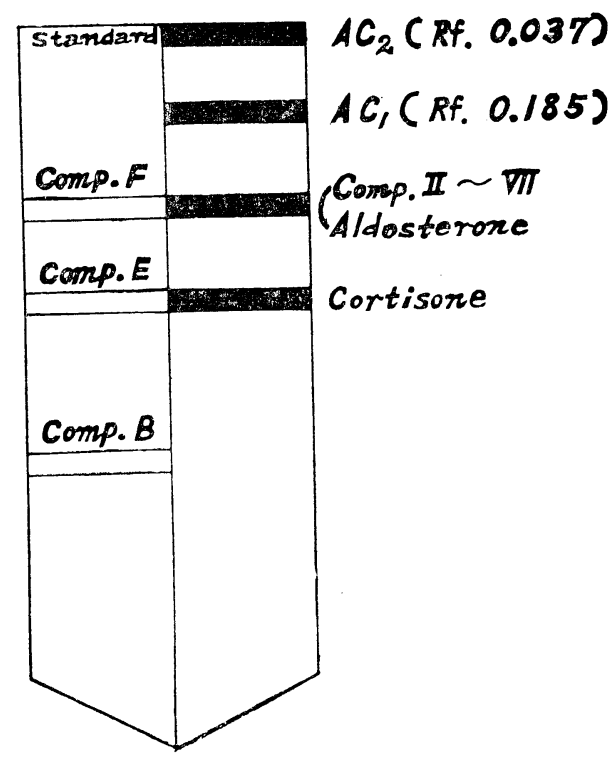

D. Bush-C System

$\mathrm{C}-\mathrm{F} \rightarrow$

"Z" fraction in C-F System

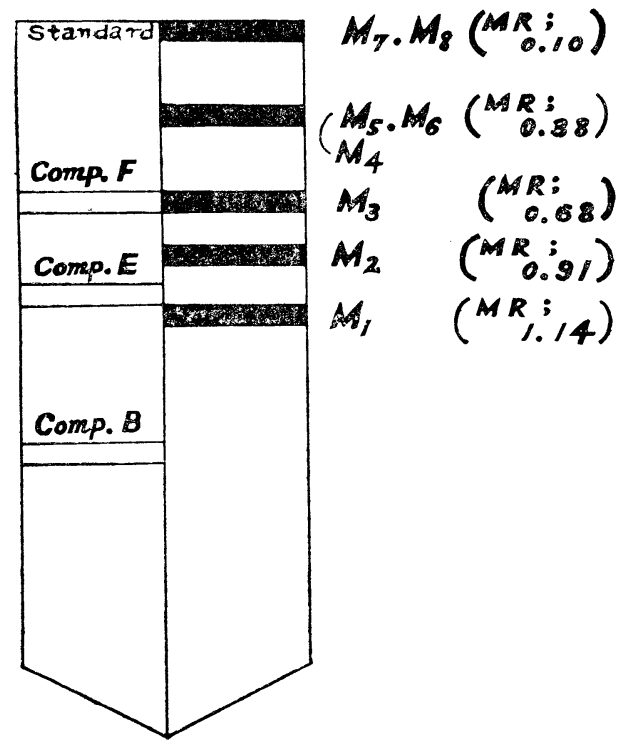

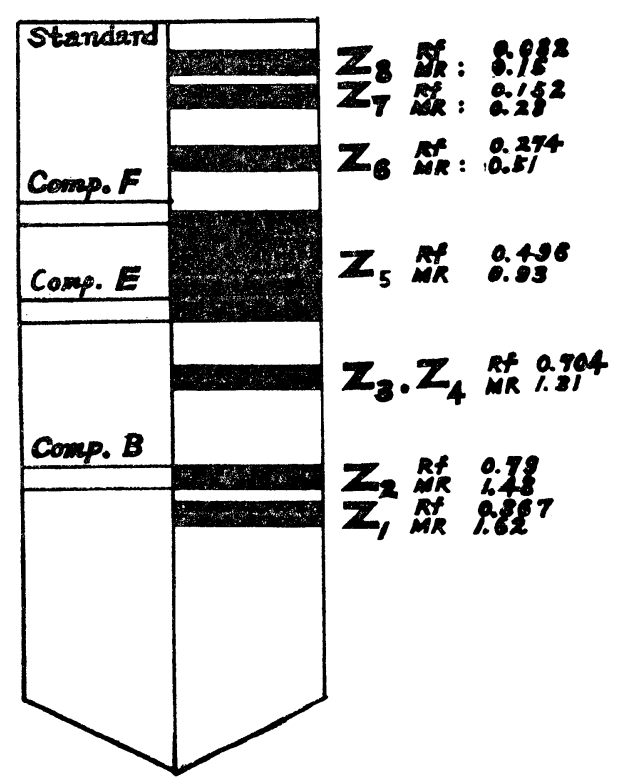


MR 蚁脳倸与ようである。

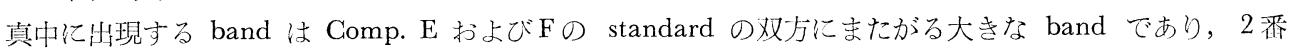
目に極性:の弱い band は Rf 0.79, MR：1.48 であり standard Comp. B に一致する band である.

\section{3. $E_{2} B$ system.}

Bush-C system によつて分離した Comp. B,E,F，Aldosterone および contaminants を $\mathrm{E}_{2} \mathrm{~B}$ system に 展開したものは図留に示すような結果となる。

i) Comp. B 相当部分

E $\mathrm{E}_{2} \mathrm{~B}$ system に上つても， standard Comp. B と一致して出現し，ほかに band の形成はみとりられなか つた.

ii) Comp. E 相当部分

C-F, Bush-C の 2 つ paper chromatography によつて分雪された Comp. E 相当蔀分注 $\mathrm{E}_{2} \mathrm{~B}$ system で現在迄に 4 種の bands に分けられた。

これは図 III B 亿示すでとく， standard Comp. E 相当部分以外に MR：0.262，1.524，1.770の3つの contaminants 者んでおり，乙れらを Comp. $\mathrm{E}_{2} \sim \mathrm{E}_{4}$ と名付けた.

iii) Comp. F 相当部分

Comp. F 相当部分加らは $\mathrm{E}_{2} \mathrm{~B}$ system で standard Comp. F に相当する band 以外に MR: 0.31 に水 色の螢光としてみとめられる band を検出し，乙れを Comp. $F_{2}$ と命名した。

Comp. B とあわせて図相Aに示す.

iv) Aldosterone 相当部分

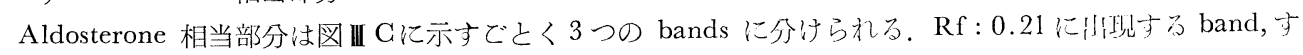
なわち中央のあのが Aldosterone 相当部分である.

図 3

\section{A. $\mathrm{E}_{2} \mathrm{~B}$ System Bush-C $\rightarrow$}

Comp. F, B. fraction. in Bush-C.

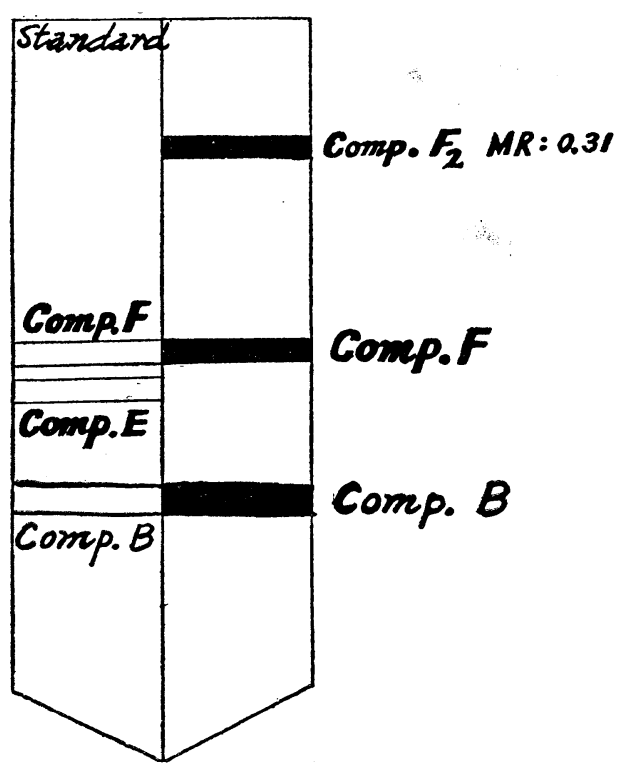

B. $\mathrm{E}_{2} \mathrm{~B}$ System Bush-C $\rightarrow$ Comp. E fraction ni Bush-C.

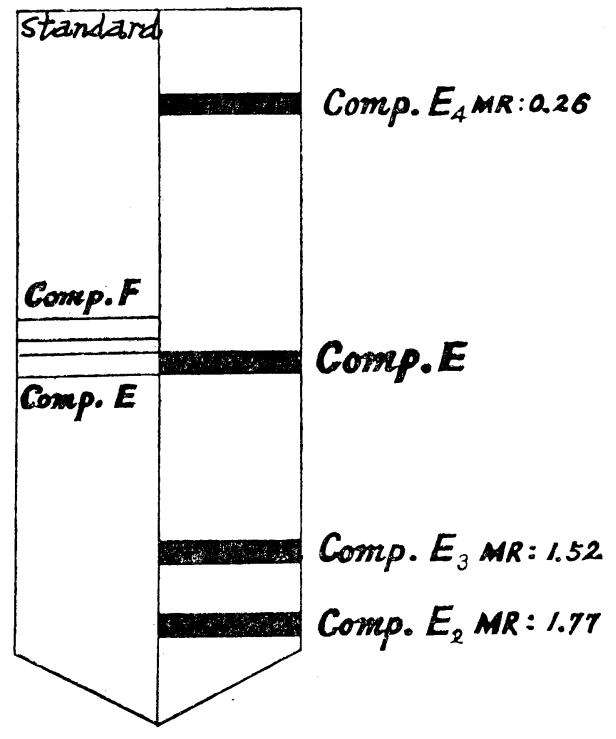


C. $\mathrm{E}_{2} \mathrm{~B}$ System Bush-C $\rightarrow$

Aldosterone fraction.

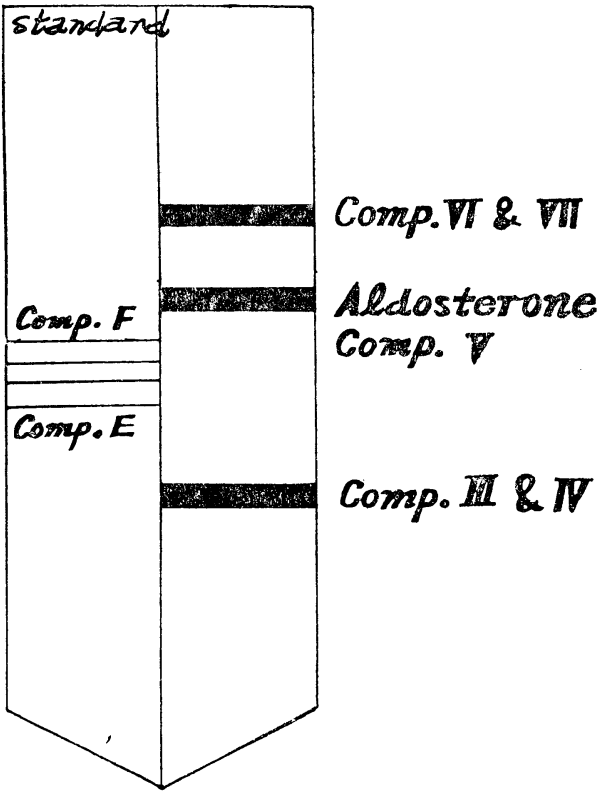

v) Contaminants.

“M” fraction 中 Bush-C system でMR : 0.38 を示したものは $\mathrm{E}_{2} \mathrm{~B}$ system で3つの bands に分 けられ，MR：1.16，0.82，0.18を示す。また同様 に Bush-G system で MR：0.10 を示したものは $\mathrm{E}_{2} \mathrm{~B}$ system で $\mathrm{MR}: 1.41,0.1102 つ 0$ bands に 分けられ，乙れを図䢐 D示す。

“Z” fraction 中 Bush-C system で Rf: 0.704, $\mathrm{MR}$ : 1.31 を示したものは図吕 $\mathrm{E}$ に示すじとく $\mathrm{E}_{2} \mathrm{~B}$ system では MR : 0.76，0.37の 2 つの bands に分 けられ，Bush-C system で Rf0.082，0.496在示す 2 つの bandsは MR : 0.126 の位䣯に同一の band として示される。

$\mathrm{AC}_{1}, \mathrm{AC}_{2}$ は $\mathrm{E}_{2} \mathrm{~B}$ でも極性沙く, start line そ

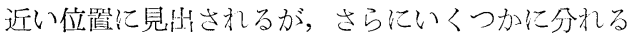
ことはない。

\section{Bush- $B_{5}$ system}

Comp. B, E, F は Bush-B system でいずれも 单一の band として，夫々の standard に一致し た band として現れる。 Comp. B，F は図4 A. Comp. $\mathrm{E}$ および $\mathrm{E}_{2} \mathrm{~B}$ で分雄された contaminant
D. $\mathrm{E}_{2} \mathrm{~B}$ Systcm Bush-C $\rightarrow$

"M" fraction in C-F.

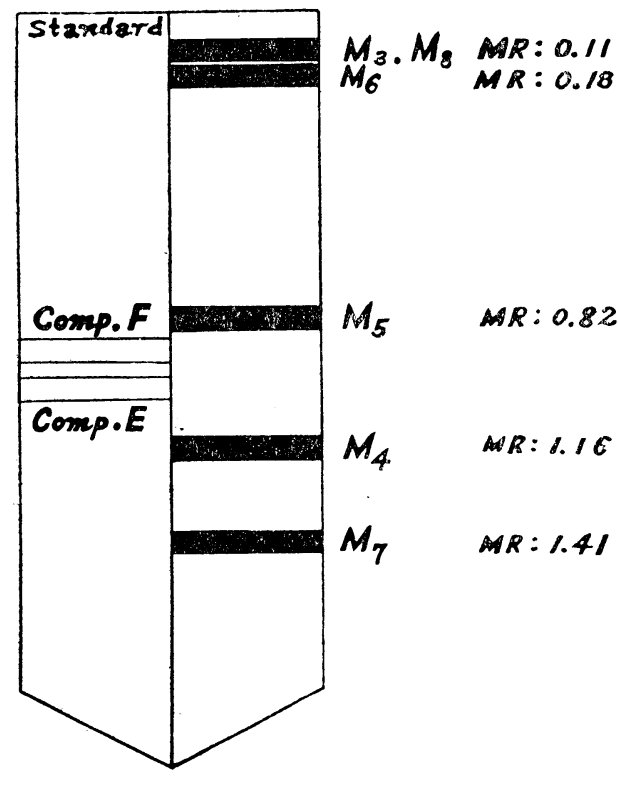

E. $\mathrm{E}_{2} \mathrm{~B}$ System Bush-C $\rightarrow$

"Z" fraction in G-F.

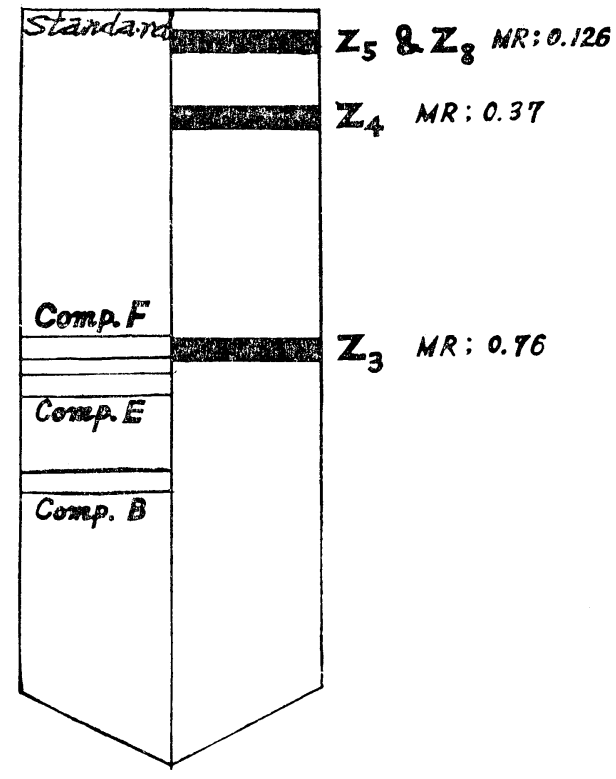


図 4

A. Bush-B

System $\mathrm{E}_{2} \mathrm{~B} \rightarrow$

Comp. $\mathrm{B} \& \mathrm{~F}$ in $\mathrm{E}_{2} \mathrm{~B}$.

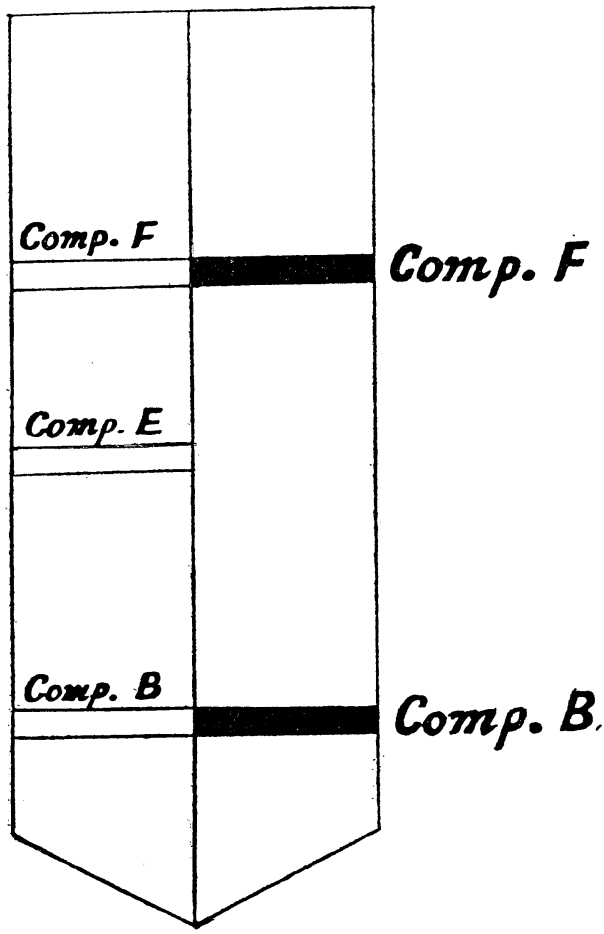

Comp. $\mathrm{E}_{4}$ は図 $4 \mathrm{~B}$ のごとく現われ，Comp. $\mathrm{E}_{4}$ の Rf は0.71，MRは1.44である。

Aldosterone は図 $4 \mathrm{C}$ に示すごとく Rf : 0.30, 0.4702 つの bands にわかれ Rf: 0.47 を示すも のが Aldosterone 相当部分である.

\section{D. 定性}

以上のごとくして得られた各 bands が目的とす るCorticoidsであるか，否かを証明するために，乙 れらの $\mathrm{H}_{2} \mathrm{SO}_{4}$ chromogen spectrum t standard のそれと比較した。

結果は図 4 に示すごとく，いずれも standard と 一致した $\mathrm{H}_{2} \mathrm{SO}_{4}$ chromogen spectrum を得た。

この各種の Corticoids の ultra viotet absorption spectrum は図 5 A 亿示すでとく, 図 5 Bの standard Comp. F のそれと一致し，滥足す心゙き程度に 純化されていること在小寸。

また $\mathrm{C}_{-}-\mathrm{F} \rightarrow \mathrm{F}_{2} \mathrm{~B} \rightarrow \mathrm{Bush}-\mathrm{B}_{\pi}$ の paper chromatogr-
B. Bush-B $\mathrm{B}_{\tilde{\jmath}}$ System $\mathrm{E}_{2} \mathrm{~B} \rightarrow$ Comp. E \& Contaminants.

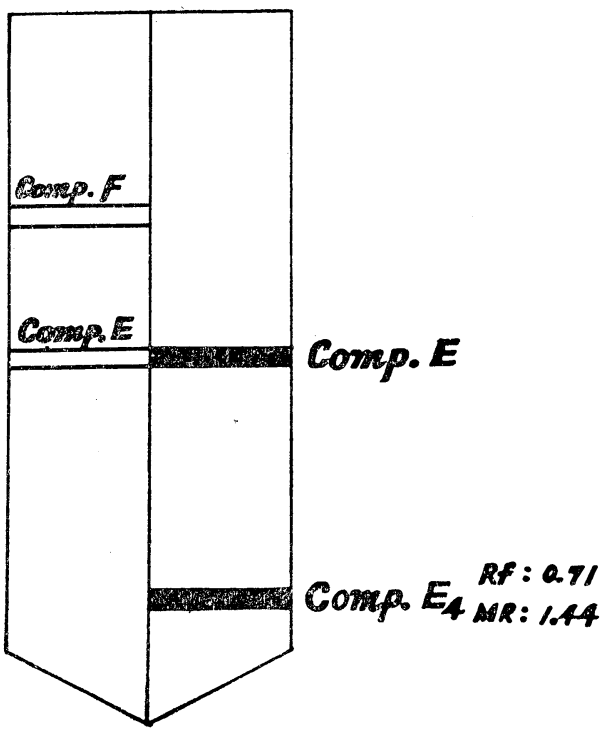

C. Bush-B System $\mathrm{E}_{2} \mathrm{~B} \rightarrow$ Aldosterone in $\mathrm{F}_{2} \mathrm{~B}$.

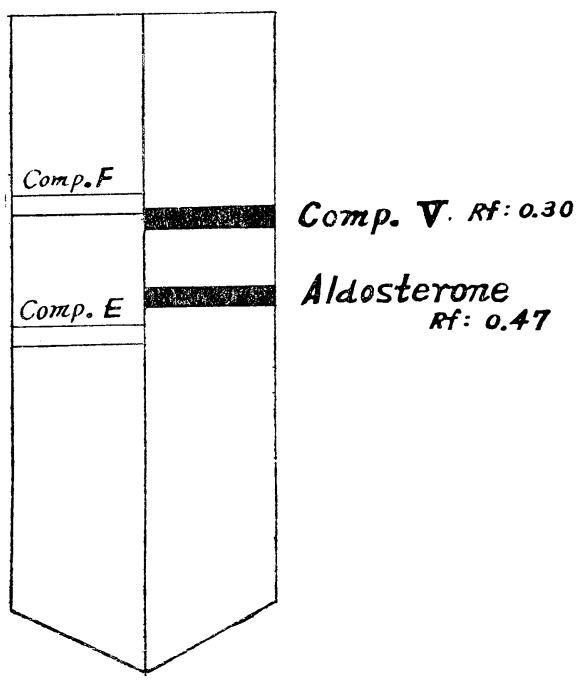


図 5 の 1

$\mathrm{H}_{2} \mathrm{SO}_{4}$ chromogen spectrum

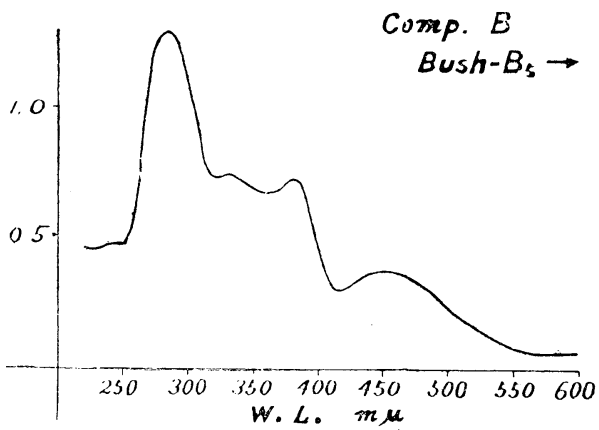

$\mathrm{H}_{22} \mathrm{SO}_{4}$ chromogen spectrum

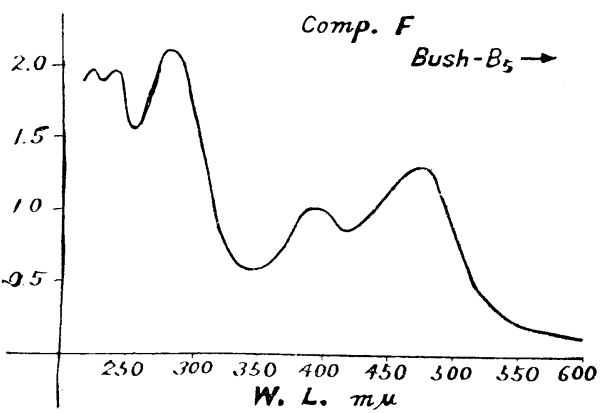

$\mathrm{H}_{2} \mathrm{SO}_{4}$ chromogen spectrum

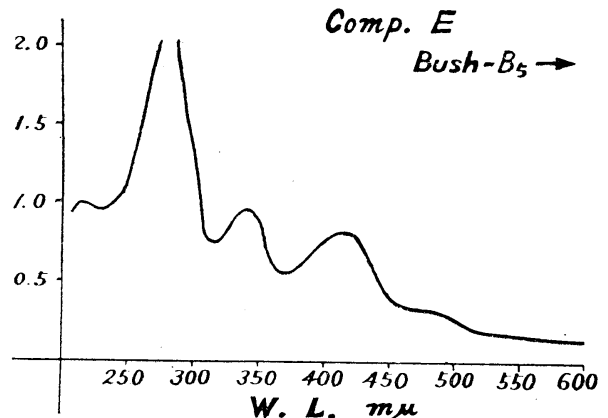

$\mathrm{H}_{2} \mathrm{SO}_{4}$ chromogen spectrum Aldosterone

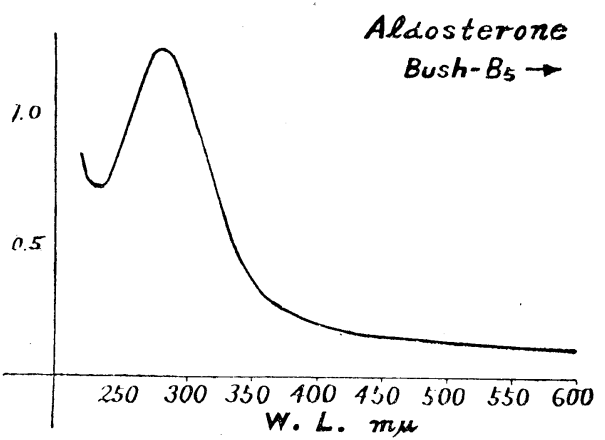

図 5 の 2

A UV absorption spectrum B UV absorption spectrum

Aldosterone, Comp.B,E,F.

$$
\begin{aligned}
& C-F \rightarrow B \text { ush }-C \rightarrow E_{2} B \rightarrow B_{5} \\
& C-F \rightarrow E_{2} B \rightarrow B \text { Bus }-B_{5}
\end{aligned}
$$
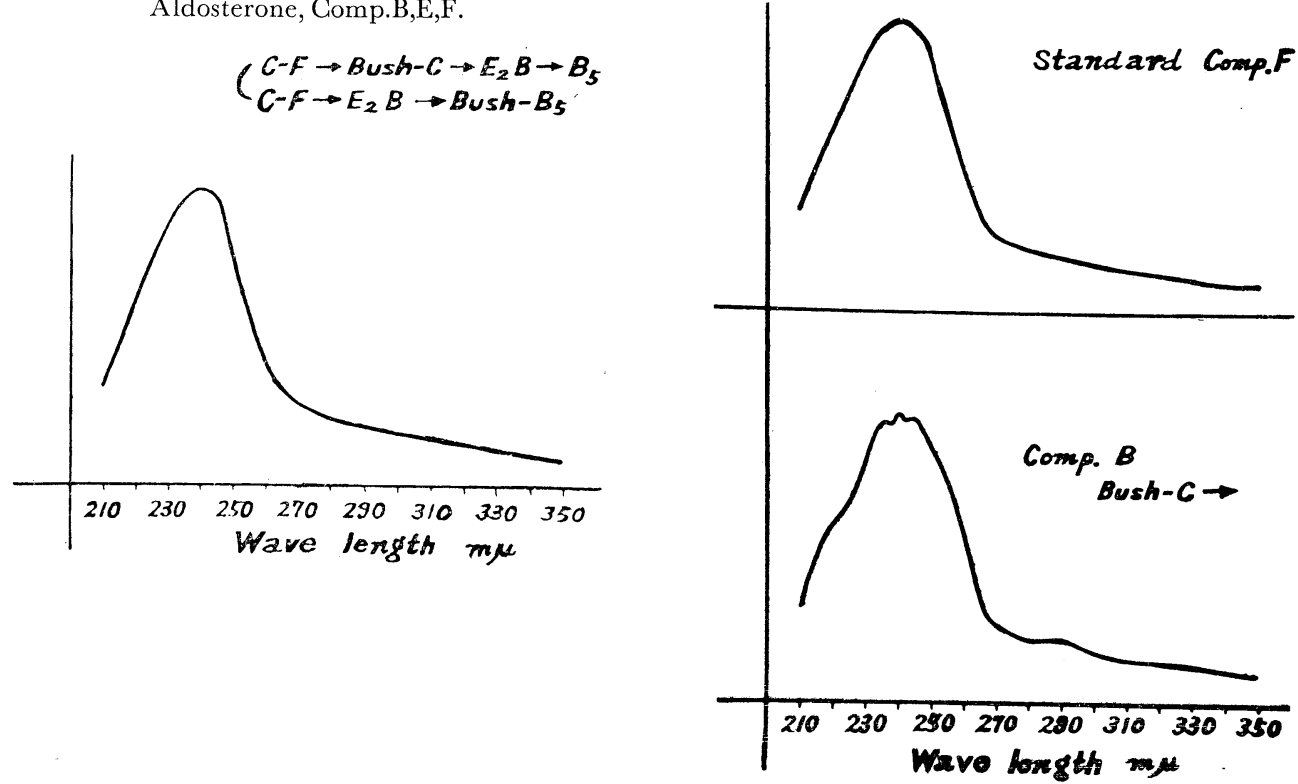
aphy の紬含せで得られた試料むこれと同様の結果を示している.

$\mathrm{E}_{2} \mathrm{~B}$ および Bush- $\mathrm{B}_{5}$ system において紫外線照射で contaminant が検出し得なかつた Comp. B の Bush-G system 後の ultra violet absorption spectrum は図 5 B そ示すでとく, peak をなす $240 \mathrm{~m} \mu$ 前後 の吸光度か活れて，curve は鋸畨状となり，なお不純であることがわかる。また同様 Bush-G system の後に $\mathrm{H}_{2} \mathrm{SO}_{4}$ chromogen spectrum を検した Comp. F では図6に示す絬果となり， curve 全体の感じは似てい るが，222m $\mu$ における小さな peak がなく，395m $\mu$ における peak が $475 \mathrm{~m} \mu$ における peak よりあ高 くなつている.

図 $6 \mathrm{H}_{2} \mathrm{SO}_{4}$ chromogen spectrum

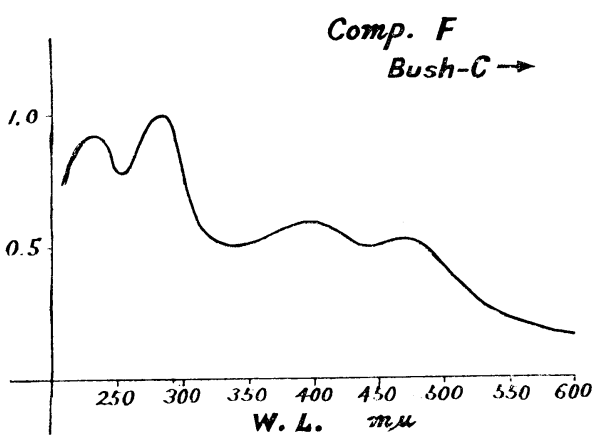

図 7

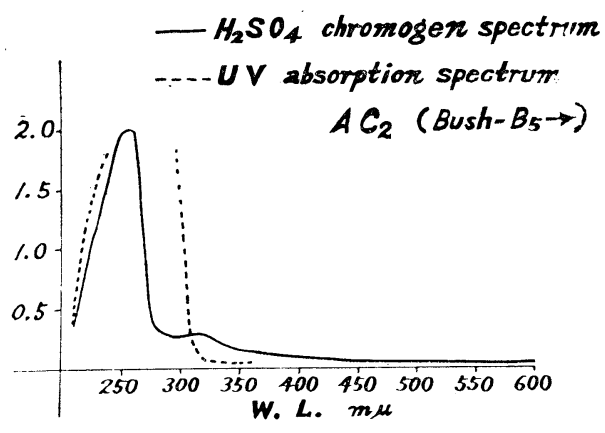

$\mathrm{AC}_{2}$ の $\mathrm{H}_{2} \mathrm{SO}_{4}$ chromogen および ultra violet absorption spectrum は図 7 に亦すように, UV 收収は

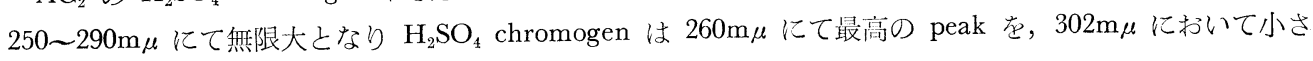
い peak を示している.

考按

\section{A. 加水分解, 抽出}

副珡皮啠より分泌せられた Corticosteroids は生体内で代謝をうけて承中に排泪されるが，free form は 少く, glucuronic acid, sulfic acid，ときほは amino acid と結合し，いわゆる conjugated formとなつて いる，乙の様なものは水に溶けやすく，乙の方法のように chloroform で抽出することが出来ず，加水分解 ということが必要となつてくる。乙れにより conjugated form より free となつたあのを抽出するのであ るが，尿中において生物学的に活性のある Corticoids がどの様な形をとつているかについては，なおいる いろの意見があり，Schneider，Cope ${ }^{19)}$ らは Comp. E, F は free かまたは glucuronide 以外の形で接沜さ れるとしているのに対して Venning ${ }^{20)}$ らはこれと文刘の立場をとつている.

いずれにせよ, free の屯のはそのまま, conjugated form は加水分解して扗出しなけ札ばならない.

加水分解の片汒としては，次の上うなう汒がとられている。

a) $\mathrm{pH} 6$ - 7 で直ちに抽谓

b) $\mathrm{pH} 4.5 \sim 6.5$ で $\beta$-glucuronidase で水解して抽法.

c) $\mathrm{pH} 1.0 \sim 1.5$ で直ちに抽出.

d) $\mathrm{pH} 1.0 \sim 1.5$ で24時間後抽出.

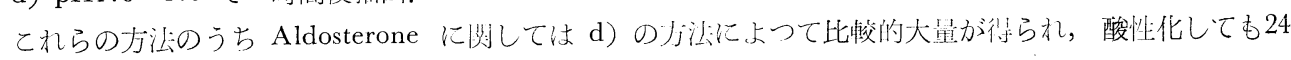

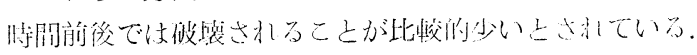

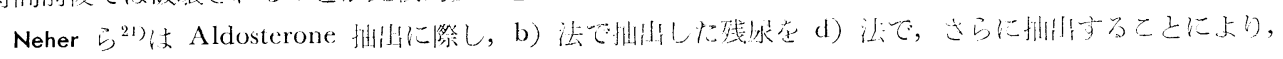

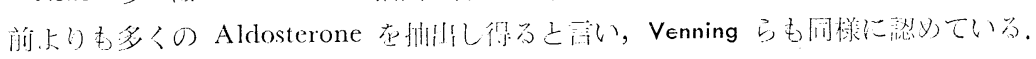


しかし，個々の Corticoids を測定するための抽出においては，Aldosterone のみを対俰とする埸合より も，考えなければならない。

したがつて， $\beta$-glucuronidase による加水分解も考慮に入れなければならない.

そこで, 理想的には, 先ずd）法沉つて酸加水分解後抽出した残尿をb）法によつてさらに加水分解し 抽出するということが必要となつてくる。酸加水分解では $\mathrm{pH}$ が酸性になる程 Aldosterone の收量が增大 すると言われているが，pH が1.0以下では加水分解過程において Aldosterone の破壊が抢こり，かつ家色 が極めて濃く，粗抽出物が赤色に近くなる。

これは $\mathrm{pH}$ による人工産物と思わ机る。

Conjugated form の抽出は水汶刘する溶解度より劣えて, 当然普通の有機溶媒では不可能であり, 水之 有機溶媒の中間的性䟨をむつ butanol が使用さ机るのであるが， butanol は Venning らによると pH 1.0 でも，その70\%を抽出するだけであり，アルカリ洗滌を行うとアルカリ液の方に移行してしまうという。

Edward ら泣 $\left(\mathrm{NH}_{4}\right)_{2} \mathrm{SO}_{4}$ 漉命の㽷に ether : ethanol (3:1) を用いて，抽出後 $\beta$-glucuronldase によ る加水分解を行つている。

抽出の原理は加水分解により水に難溶性となつた free form の Corticoids 老 chloroform に移すのであ るから, free corticoids の chloroform に対する溶解性により抽出率は当然異つてくる.

Comp. B, E, DOC は Comp. F に比べて, 同じ回数の連続抽出であ，抽出率が演く， 5 回連続抽出で Comp. F の80\%に比べて $95 \%$ となつている。 また Comp. B, E および DOG では7 回目以後に抽出した chloroform には試料を含有していないが，Comp. F では 8 回目の抽出で Comp. B, E の 6 回目位に相当 する量が検出される。このととは 5 回連続抽出では Corticoids 測定に不充分であると言える.

著者は Aldosterone 在所有していないので，Aldosterone を使用した抽出率在求めることが出来なかつ たが，乙の実験絬果より，個々の Corticoids 去分離定量するためには少くとも0.1容の chloroform では 8 回の連続抽活を必要とする，rotary flash evaporator 在使用しての乾固による loss は技術的な問題である が，熟練すれば非常に少いもの之考劣る。

B. Chromatography.

1. Column chromatography.

Aldosterone の分離定量は Column chromatography に Florisil 父は Silicagel が用いられる。

Comp. B，E，F を使用しての Florisil column chromatography の回収率はほとんど100\%に近い.

これは滴下を分時60滴とした場合であり，80滴とすると1\%および chloroform 分劃にあ出現がみられ， 回收率汁下る。

この成績をみると60滴としても chloroform 分劃に微量出現ぶある様に思われるが，乙れは試料を含む量 と関係のないとと，および $1 \%$ 分劃に全く出ないとと，微量であるとと，より reagent blank の誤差範位 と考光ら礼る。

Aldosterone そついては行わないが，乙れらの成繢より考元て，やはり100\%近い回收率が得られるむの と思う。

このう法は，次の paper chromatography の前段階として行うもので， loss が可成り大きければ，粗抽 出物の少い之きは直接 G-F system 亿展開してもよいが，ての四收率より学えると， contaminants を或る 程度制限し，試料をのせる滤紙面が少くてすむという利点より，Neher，Wettstein のでとく量によつて行う ということでなく，す心゙てに適用してよいと考える。

Silica gel と Florisil との間には定量的には優少はないとされており，次の C-F system を行うとき， どの様な contaminants を多くもちてむかがこの差となつてくる.

B. Paper chromatography.

1. Corticosteroids 分離における paper chromatography に関する技術的事項

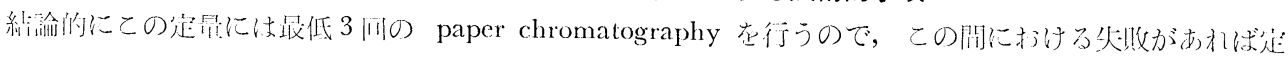


量不可能となる。

失敗はまた，ほとんど paper chromatographyにおいておこり得るので，特に注意を必要とする，著者 の経験では，特に C-F system において技術的に困難を来すととが多い.

小田一石井法による㽷中 Aldosterone 定量法は最初 C-F system の代りに Zaffaroni による toluenepropylenglycol system 老使用していたがその展開時間が非常に長く, ただでさえも複雑をきわりる Aldosterone 定量法であるので, 時間短縮の意味で G-F system を採用した.

また Comp. E とFの分離能すすぐれているので，乙れを使用した。

C-F system で Comp. E と Comp. F を分離するのに，技術的に最む大切なととは tank 内部の chloroform gas の飽和というととである.

これが不充分のときは solvent front が鋸画状となり, 傾いて流れたり, 時には front が途中で stopす る. このために, paper を setする前に tank の内面の滤紙に chloroform を充分かけて, すばやく set する。

paper を吊すのむtank の壁にどちらか一方が辺よりすぎていては斜に流れることがある.

tank 之蓋は, その接触面に硬質のグリスを奴り, 内圧で蓋が上つたり, gas があれたりしない様に固定 具をかけておく必要がある.

paper を処理する formamide はその濃度が高い之展開時間は延長するが分離能は高くなる．ただこの両 者を考光るときは，やはり $20 \%$ formamide in aceton が適当であろう.

paper の処理が終つたら，直ちに陚料をのせるのであるが，乙れる時間をかけすぎると，分離が悪くな る。

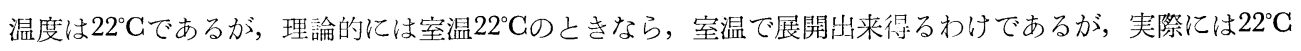
以下の室温で恒温槽内で行うのが分離がよい.

この理由については，なお不明であるが，あるい湿度にも関係するかす知れない。

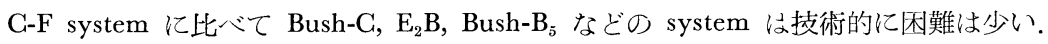

原法に従えば，乙れらの system は飽和を必要としているが，著者は移動首を tank 内面にかけて，飽和 時間を零にして行つたが，展開時間および分離能に関係なく，時間的に短縮する意味では推賞出来る。

\section{Contaminants.}

Neher \& Wettstein 法, あるいはこの変法において Aldosterone と考えていたあのの中に，現在迄に 6 種 の Aldosterone 以外の Contaminants が発見されており，て机ついては Nowacynski ${ }^{22}$ らによつて詳細 に報告されており，Comp. II は 11-Dehydroaldosterone であるととあ判明した ${ }^{232}$.

著者も Bush-G system における Aldosterone 相当の band より contaminants を分離したが，これら の物質の Rf の値より，彼等の Comp. III, V, VI, III 亿相当するものと考えられる.

また Bush-C system における Comp. E 相当の部分より，新たに 4 種の contaminants を分離し，乙れ を Comp. $E_{2} \sim \mathrm{E}_{4}$ とした. 又 Comp. $\mathrm{F}$ 相当部分加ら contaminant として Comp. $\mathrm{F}_{2}$ を分離したが， これらの他に $\mathrm{M}_{1} \sim \mathrm{M}_{8}, \mathrm{Z}_{1} \sim \mathrm{Z}_{8}, \mathrm{AC}_{1}, \mathrm{AC}_{2}, \mathrm{HC}_{1} \sim \mathrm{HC}_{3}$ の21種の contaminants を分離したが，本邦にお いては稲葉 ${ }^{24)}$ ，岡田 ${ }^{25)}$ にり分離された contaminants がいくつか報告されているが，両者共 G-F system でなく toluen-propylenglycol system を使用しているので，著者の分離した contaminants のどれに相当 するかは不明である。欧米においても Hernando ${ }^{26)}$ Brook ら ${ }^{27)} の$ contaminants について報告があるが， これらの報告の各種 paper chromatography における Rf 值より考えると，著者の分離したもののうちの 幾つかであると思われる。

Brook らの報告している contaminant は Bush-C system において Comp. Fよりも, さらに極性の强 いもので Wildegosterone と呼んでいるが，これと Aldosterone が何らかの関係を有するような興味ある ことを報告している.

すなわち Wildegosterone は娃娠時に增加し, Addison 氏病患者で, Aldosterone, Wildegosterone と屯 第36巻 第 6 号 
に見られないものに Aldosterone を負荷し，尿中に Aldosterone および Wildegosterone 排泄をみてい る。また Wildegosterone は $\mathrm{KCl}$ 投与で増加することを報告しているが，著者の分離した contaminants のうち, Bush-G, $\mathrm{E}_{2} \mathrm{~B}$, Bush- $\mathrm{B}_{5}$ の system そおいて極性が強く, $\mathrm{KCl}$ 投与で著明に增加したのは $\mathrm{AC}_{2}$ で あり，これより考えて，あるいは $\mathrm{AC}_{2}$ とWildegosterone が同一の物質であるかも知机ない.

Aldosterone を負荷して，乙坊かとめられるようになつたと言うことは，本物質が， Aldosterone の代 謝産物ではないかという疑を持たせる。

いずれにせよ問題になるのは著者の分離した多くの contaminants が副腎皮澌ホルモン中の何に由来する かと言うことである。

もちろん生物学的に活性の Corticosteroids の代謝産物屯含まれるであろうし，非活性のあの，あるいは その代謝物も含まれるであろう。

これらの由来を追求することは生体内における Corticosteroids 分泌を何う上に極めて重要なとととなつ てくる。しかし，いろいろに代謝されているものをすべて合成し，乙れらの $\operatorname{Rf}$ 值， $\mathrm{H}_{2} \mathrm{SO}_{4}$ chromogen， ultra violet absorption，などを検することは不可能なととではある.

しかし生物学的に活性の 7 種の Corticosteroids の $\mathrm{C}^{14}$ で lavel したものが出来机ば，乙机を生体に負 荷し，尿中の Corticoids を分離する際，paper chromatography のどんな Rf を示して $\mathrm{C}^{14}$ を含むものが 出現するかを追求すれば解明出来る問題である.

これらの contaminants を容易に分離し得るようにすることが paper chromatography の system を決 定する条件となるが，やはり必要なあのは standard の Corticoids である。

その意味で Comp. B, E, F などは18位のCが methyl 基となつているために，天然に存在する steroids， たと壳ば desoxychol 酸などから，その化学構造の一部をかえ，いわゆる部分合成によつて作り得るので便 利であるが，Aldosterone は methyl 基でなく aldehyd 基であるためこの様な steroid は夫然に存在せず， 全合成によらねばならないたり，入手が極りて困難でこれを standard に用いることがすずかしい，G-F，

Bush-G system のごとく, Aldosterone の Rf 值が standard の Comp. F，E などとほとんど一致する 屯のはよいが， $\mathrm{E}_{2} \mathrm{~B} ，$ Bush- $\mathrm{B}_{5}$ などの system では 全く別の band となるので，乙の場命どの band が Aldosterone か在見分けるのは Rf 值にたよら ざるを得ない.

ところが paper chromatography における Rf 值は著者の得た值と Nowacynski, Venning らのそれ と比べると多少ではあるが異つている。

したがつて，乙の様な system ではをの前に極小 contaminants を除去しておかないと，切りとつた band が目的以外のものであるという可能恻も折て くる.

たとえば，著者が現在迄に分離した contaminants が1つの sample において 全部出たとする と，この際 C-F system より Bush-G を通さずに $\mathrm{E}_{2} \mathrm{~B}$ system 亿加けたさき図 8 亿示すようにいく つもの bands の出現をみる。あるいは新しい contaminants が Aldosterone の付近に検出された とすると，非常に難しいことになる。このように考
図 $8 \quad E_{2}$ B System

$$
\mathrm{C}-\mathrm{F} \rightarrow
$$

"Comp. F" fraction in C-F.

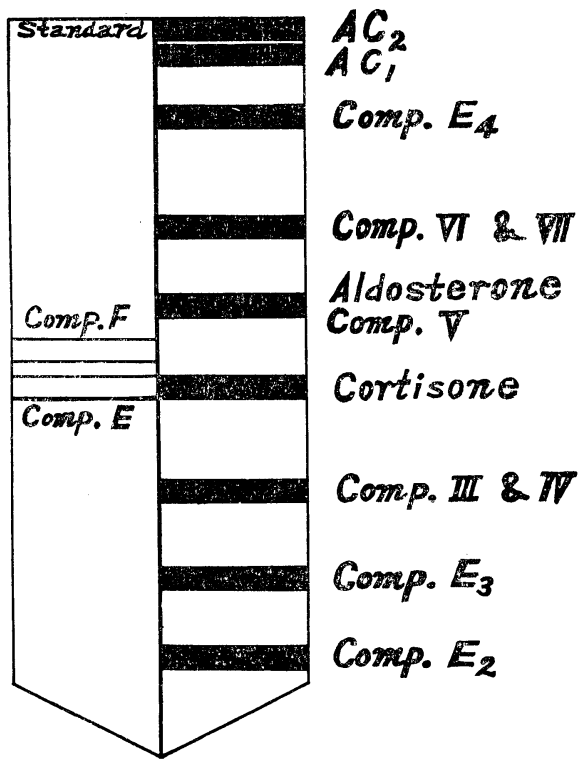


えると Bush-G system はやはり大切になつてくるわけである.

\section{Comp. B, Comp. E, Comp. F およびAIdosterone の純䗋分離}

これらの Corticoids を最終的に比色定量するときに，個々のものに特異的な化学反応を利用して行われ るならば，いくつあの paper chromatography を組合せて純化する必要はないが，現在ではてれがなく， したがつて，純するというととは不可欠の条件となつてくる.

paper chromatography を重ねてゆくときに，対象とするもの以外に contaminant を分離し得る間は純 化されたとは言えない.

したがつて Bush-G system の後に Aldosterone, Comp. E, F を測定することは䛊りであるといえる. Comp. B は $\mathrm{E}_{2} \mathrm{~B}$ system で Mineralight 照射により contaminant の存在はなかつたが，乙の方法はUV 吸収法であるから， $\alpha-\beta$ 不飽和ケトン基を有するものしか検出されず，乙れ以外のものは見えないが，存在 を否定出来ない，UV absorption spectrum によつて不純なととが判つたのはこの点である.

UV absorption spectrum は standard のそれと比較するとき，その一致の度合は sample の純化の度 合を示すむのとされている.

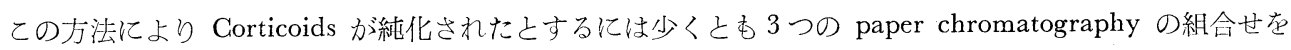
必要としている。 すなわち $\mathrm{C}-\mathrm{F} \rightarrow \mathrm{Bush}-\mathrm{C} \rightarrow \mathrm{E}_{2} \mathrm{~B} \rightarrow \mathrm{Bush}-\mathrm{B}_{5}$, あるいは $\mathrm{G}-\mathrm{F} \rightarrow \mathrm{E}_{2} \mathrm{~B} \rightarrow \mathrm{Bush}-\mathrm{B}_{5}$ である.

これにより純化されたと思われる物質がはたして目的の Corticoids であるかる検するため $\mathrm{H}_{2} \mathrm{SO}_{4}$ chromogen spectrum を standard と比較して，乙れに一致するととをみとめたが，乙の curve は各種の steroids に特有の peak をなすととが知られている。この curve は steroid の化学構造には関係はないが, $\Delta^{4}$-3-Keto 基を有するあのは 280〜 $290 \mathrm{~m} \mu$ において獝い吸収をみとめる。 また free form と $\mathrm{C}_{s}, \mathrm{C}_{5}, \mathrm{C}_{11}$, $\mathrm{C}_{20}, \mathrm{C}_{21}$ の mono acetate は全く同一の spectrum を走すとされている.

純化されない物質ではすちろん standard とは変つた型のものが得られる.

これらの成績によつて間違なく純化された Aldosterone, Comp. B, Comp. E, Comp. F が系統的に測定 し得るのであるが，DOG はこれらの Corticoids 分漼のための paper chromatography では極性が非常に 弱く，1\% methanol in chloroform に出現するものを全く別の paper system で分離純化して行かなけ ればならない.

Comp. B，E，F および Aldosterone を純化する際に，仮に Comp. B が 2 回の paper chromatography

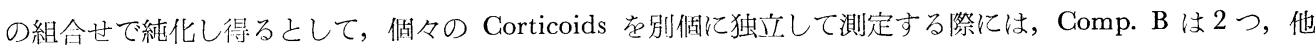
は3つの paper chromatography を組合せて測定してもよいわけであるが，相対的にその量を論じるため には，すべて全く同じ過程を通さねばならない，生体における電解質代謝に関与するあのは，乙れら生物学 的に活性の Corticoids の綜合されたものであるばかりでなく，最近 Ross ${ }^{29}$ の報告によれば Aldosterone 省独負荷と Comp. B との同時負荷とを比べると, Aldosterone+Comp. B の負荷は Aldosterone 単独よ りも $\mathrm{Na}$ 苗積性が抑制され，K排泄が促進するという。乙れは彼も言うごとく，Conn 症候群の病態解明 の上から極めて興味深いととである。著者むConn 症候群患者の尿中より，現在迄に経験したうち最む大 量の Comp. B を検出したととと考えあわせ興味ある事実である.

このように電解質声納の面より芫ても, 単に Aldosterone のみを測定して满足出来るあのではなく, Corticoids のすべてを測定し，その相対的值より推測すべきととである.

次に間題となることは，乙のように純化した free form がはたして生体内に扔てての分泌を反影する か否かということである。

特に Aldosterone のでとく分泌機序が不明であるものの分泌規制因子を追求するのには，乙の点が重大 な問題となつてくる.

尿中物質を測定するには free form のほかに metabolite されたものの測定が不可欠であり，この量が free form よりあはるかに多いであろうことは著者の分離した contaminants をみても明白な事実である. これを総会してはじめて生体内におけるその分必を。さらには生理的, 病理的意義を伺うことが出来るので 
ある。

分泌調節因子の追求には当然，真に分泌を反映する様な方法をとらねばならず，協研者吉沢 ${ }^{30)}$ は犬副腎静 脈血中の Corticoids 定量法を，横田 ${ }^{31}$ は各種条件下における变動について発表している.

著者は paper における spot の確認に UV 吸収法を用いたが，なおこれによつてみとめられない contaminants む存在している.

tetrahydrocorticoids がそれで，乙れは $\alpha-\beta$ 不飽和ケトン基をもたないため，乙の方法ではみとめられ ない，かつこれは可成りの量が存在するとされ，でく微量の代謝産物は別としても，てれは測定の一部に加 えなければ，生体での分泌を伺うことが無理である.

このように考元ると純粋に分離するということが臨床上どのような意味をむつかという疑問が生じてく る. その上 1 回の paper chromatography の実施による loss は10〜20\%であり，4回の paper chromatography を行光ば，その回收率がいかに低下するかがわかる。しかし metabolited form の測定について は将来にゆずるとして，現在の段階では，free form の測定法がまず問題となり，このためには純化という ことあ必要になつてくるのである.

\section{C. 定量}

定量法としては現在 UV 吸収法および BT 法の 2 法が一般に用いられている.

Aldosterone について UV 法， BT 法の 2 方法で同一試料を測定した絬果は Venning らの報告にみられ るが Bush-C, $\mathrm{E}_{2} \mathrm{~B}$ system のあとでは UV 法が高い值を示している。

UV 法は $\Delta^{4}$-3-Ketone 亿共通の反応であり，BT 法は20,21- $\alpha$ Ketol あるいは 17-OH 20,21- $\alpha$ Ketol に其通の反応であり，UV 法で高い值を示したととは，BT 陰性の contaminant の存在を暗示するもので ある。

方法としては，なにぶん微量物啠であるから paper blank の低いことが望ましく，ての点であ BT 汇が 用いられ，また BT 陰性物啠を除外する意味にあなる。

しかし metabolited form をあ測定するというととにな礼 BT 治，UV 汒も陰性なものが出現し，满 足な方法とはいえない，Porter-Silber 反応にしても Aldosterone は陰性である。この点に関してあなお准 歩の余地が多い.

ただ純粋分離を行つた free formに関してはBT 法で满足出来るむのと言える。

\section{結 論}

著者は尿中の Aldosterone を中心とした Corticosteroids 分離定量泛について検討し，つざの絬果を得 た.

1) Chloroform による抽出過程における回收率は Comp. F では 80\%，Comp. B，E，および DOC で は95\%である。

2) 連続抽出をさらに行う之, Comp. $\mathrm{B}, \mathrm{E}$ および DOC は 7 四以後倹出されないが，Comp. F では 8 网目において，Comp. B，E の6回目之ほぼ同量のむのが検出される。

これより木定量には 8 回の連続抽出を必要とする。

3) Florisil column chromatography においては, 分時60滴の滴下条件では Comp. B, E, F は $25 \%$ methanol in chloroform に出現し，その回収率は約100\%であるが，滴下数を80滴とすると $1 \%$ methanol in chloroform および chloroform fraction にも出現し，回収率は低下する。

4) paper chromatography において Bush-C system そおける Aldosterone 相当の band より Comp. III， V， II，III を分離した。

5) Bush-C system にわける Comp. E 相当の band より新たに未知の物湎である Comp. $\mathrm{E}_{2} \sim \mathrm{E}_{4}$, Comp. $\mathrm{F}$ 相当の band より Comp. $\mathrm{F}_{2}$ を分晟した. このほか, 未知の $\mathrm{Z}_{1} \sim \mathrm{Z}_{8}, \mathrm{M}_{1} \sim \mathrm{M}_{8}, \mathrm{AC}_{1}, \mathrm{AC}_{2}, \mathrm{HC}_{1}$ $\sim \mathrm{HC}_{3}$ の21種の contaminants を分離した。 
6) Comp. B, E, F および Aldosterone の純化を ultra violet absorption spectrum により検し，乙れ らの純化には $\mathrm{C}-\mathrm{F} \rightarrow \mathrm{Bush}-\mathrm{C} \rightarrow \mathrm{E}_{2} \mathrm{~B} \rightarrow$ Bush-B , あるいは $\mathrm{G}-\mathrm{F} \rightarrow \mathrm{E}_{2} \mathrm{~B} \rightarrow \mathrm{Bush}-\mathrm{B}_{5}$ の 3 または 4 つの paper chromatography の組合せを必要亡する。

7) これにより得られた試料の $\mathrm{H}_{2} \mathrm{SO}_{4}$ chromogen spectrum は standard のそれに一致し，乙れらが目 的の Corticosteroids であることを同定した.

本稿を擱筆するにあたり御指導, 御校閲を賜つた恩師大島研三教授, 御援助を載いた久代登喜男助教授, 直接研究の御指導を戴いた小田立男講師に潹謝するとともに日夜御協力を戴いた石井昭郎博士はじ大島内 科代謝班員各位，ならびに研究室助手の方々に感謝致しまず.

文献

1) Tait, J.F., et al. : Lancet 2621221952.

Simpson, S.A., et al. : Experimentia 101321954.
2) Tait, J.F., et al. : Nature 1697951952. 1163, 1954.5）小田立男：日本医事新報，1729, 37, 1957 .

4) Simpson, S.A., et al. : Helv. Ghim. acta 37,

7) 村井隆三：日大医誌. 19, 513, 1960

Endoclinol. 12519 1955. 195131960 .
8) 菅沼 勲：日腎誌, 2, 169, 1960. 1956. 11) 小田立男. 鈴木敏弘他：ホルモンと臨床，7，940，1959. 12$)$ 大島研三. 他: 日本循 環器学会 1960年総会.

13) Zaffaroni, A. : Recent Progr. Hormone Res. 8, 51, 1953. Bush, I.E. : Biochem. J. 50, 370, $1952 . \quad 15)$ Eberlein, W.R., et al. : Arch. Biochem.Biophy. 59, 90, 1955. 16) Zaffaroni, A. : Recent Progr. Hormone Res. 8, 51, $1953 . \quad 17)$ Gornall, A.G., et al. : Can. J. Biochem. Physiol. 35, 71, $1957 . \quad 18)$ Simpson, S.A., et al. : Helv. Chim. Acta 37 1163 1954. 19) Nowacynski, W., et al. : J. Lab. \& Clin. Med. 45, 818, $1955 . \quad 20)$ Schneider, et al. : J. Biol. Chem. 194, 337, $1952 . \quad 21)$ Venning, et al. : Recent Progr. Hormone

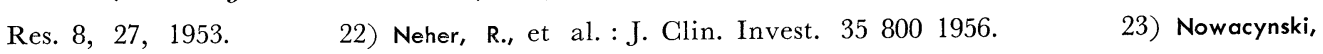
W.J. et al. : Can. J. Biochem. Physiol. 34, 1023，1956. 24 ) 稲葉 稔: 日本内分学会第32回総会 25) 岡田弘二 : ホルモンと臨床，6，738，1958. 26) Hernando, L. et al. : Metabolism 6, 518, $\begin{array}{lll}\text { 1957. 27) Brook, R.V. et al. : Lancet 3, 925, } 1956 . & \text { 28) Zaffaroni, A. et al. : J. Biochem. }\end{array}$ 193，749，1951. $\quad 29)$ Ross, E.J. : J. Endocrinol. Metab. 20，229，1960. 30) 吉沢甚一郎 : 日本内分泌学会雑誌. 36, 200, 1960. 31) 横田睦雄 : 日本内分泌学会雑誌 36, 199, 1960. 